\title{
The Assimilation and Retention of Carbon in Upland Heath Plant Communities Typical of Contrasting Management Regimes: $A^{13} \mathrm{C}$ Tracer Study
}

\author{
Samuel L. O. Quin,, ${ }^{1,2}$ Tara R. A. Conolly, ${ }^{1}$ Rebekka R. E. Artz, ${ }^{2}$ \\ Andrew Coupar, ${ }^{3}$ and Sarah J. Woodin ${ }^{1}$ \\ ${ }^{1}$ Institute of Biological and Environmental Sciences, University of Aberdeen, Cruickshank Building, Street Machar Drive, \\ Aberdeen AB24 3UU, UK \\ ${ }^{2}$ The James Hutton Institute, Ecological Sciences Group, Craigiebuckler, Aberdeen AB15 8QH, UK \\ ${ }^{3}$ Scottish Natural Heritage, Great Glen House, Leachkin Road, Inverness IV3 8NW, UK \\ Correspondence should be addressed to Samuel L. O. Quin; squin@abdn.ac.uk
}

Received 20 January 2013; Accepted 17 March 2013

Academic Editor: Wen-Cheng Liu

Copyright @ 2013 Samuel L. O. Quin et al. This is an open access article distributed under the Creative Commons Attribution License, which permits unrestricted use, distribution, and reproduction in any medium, provided the original work is properly cited.

Upland heath is an extensive habitat in the UK and is currently managed for a range of objectives: agricultural grazing, sporting interests, and biodiversity conservation. Increasingly land management will also have to address the provision of the ecosystem service of carbon sequestration (transfer of $\mathrm{CO}_{2}$ from the atmosphere into long-lived pools for storage). This study investigates carbon sequestration in Calluna- and Nardus-dominated upland heath vegetation communities in NE Scotland, which typically occurs as a result of low and high intensity management (grazing and burning) regimes, respectively. $\mathrm{A}^{13} \mathrm{CO}_{2}$ tracer experiment compared the rate of carbon assimilation and the retention of assimilated carbon over six weeks during the growing season between these two communities. There was no difference in ${ }^{13} \mathrm{CO}_{2}$ uptake between Calluna- or Nardus-dominated vegetation communities and they both retained over $40 \%$ of the assimilated ${ }^{13} \mathrm{C}$ after six weeks. The ${ }^{13} \mathrm{C}$ retained was mostly held in Calluna leaf and stem tissue in the Calluna-dominated community and in graminoid leaves in the Nardus-dominated community. Consideration of the strategies of the dominant species and the attributes of the tissues in which ${ }^{13} \mathrm{C}$ was retained suggests that Calluna-dominated vegetation may be of greater benefit to carbon sequestration in the longer term.

\section{Introduction}

The management of ecosystems for carbon (C) sequestration, defined as the transfer of $\mathrm{CO}_{2}$ from the atmosphere into long-lived $\mathrm{C}$ pools for storage [1], has become a national and an international objective [2-4]. C stocks within different ecosystems in the UK are fairly well quantified [5], but estimating changes in stocks in response to land management is more difficult $[6,7]$.

There are 1.2 million hectares of upland heath within the UK, the majority in Scotland [8]. Upland heath in "favourable condition," is dominated by dwarf shrubs ( $>25 \%$ cover), typically the evergreen ericoid Calluna vulgaris (hereafter referred to as Calluna), with graminoids and mosses interspersed. This habitat is predominantly underlain by organomineral and organic soils, with organic matter up to c. $0.5 \mathrm{~m}$ deep. The average upland heath soil $\mathrm{C}$ density is $89.9 \mathrm{tha}^{-1}$ in the top $15 \mathrm{~cm}$ of the soil [9], representing a national $\mathrm{C}$ stock of $108 \mathrm{M}$ tonnes and significantly more if total soil depth is accounted for. Given the importance of this habitat as a $\mathrm{C}$ store, we need to understand the consequences of different land management practices for $\mathrm{C}$ sequestration and storage.

Upland heath is traditionally managed by low intensity grazing and rotational burning, creating a mosaic of different aged Calluna stands, providing young, nutritious plants for all-year round forage and older, larger plants as cover for wildlife, notably important bird species [10]. Upland heath 
has suffered significant decline and although its total extent has stabilised in recent years, its condition remains variable $[8,11]$. Much is currently in "unfavourable condition," characterised by the replacement of dwarf shrubs with graminoids, typically as a result of over grazing and/or poor burning practice [12]. One graminoid which commonly becomes dominant is Nardus stricta (hereafter referred to as Nardus), a tussock-forming perennial grass of low nutritional value which is less preferred than Calluna by grazing animals [13, 14]. The dominance of Nardus over large areas is thus of less benefit to agriculture and biodiversity conservation than a Calluna sward.

Change in plant species composition can influence ecosystem C dynamics [15-20]. Calluna, an evergreen shrub, exhibits a slow growth rate [21] and produces long-lived leaves, with low $\mathrm{N}$ content and high concentrations of phenolics $[22,23]$ and lignified woody stem material. Thus, Calluna litter is recalcitrant, resisting decomposition and reducing soil respiration. Graminoids exhibit contrasting traits, with faster growth enabling rapid $\mathrm{C}$ assimilation but also resulting in greater $\mathrm{C}$ loss through plant respiration [16]. Faster growing species also tend to produce leaves with shorter lifespan and higher $\mathrm{N}$ content, thus, generating large amounts of litter and increasing rates of decomposition and subsequently soil respiration $[23,24]$. Shifts in abundance of subdominant functional groups following change in dominant species may also influence $\mathrm{C}$ dynamics; metabolically active herb species have labile plant litter which is easily decomposable, whereas moss species are slow growing and produce recalcitrant litter [25]. Thus, a shift between Calluna and Nardus dominance of upland heath could alter the $\mathrm{C}$ balance of the system; it would be predicted that a Calluna-dominated system would be a stronger carbon sink than a Nardus-dominated sward.

This study employs an in situ ${ }^{13} \mathrm{CO}_{2}$ pulse labelling experiment to compare $\mathrm{C}$ assimilation and retention in upland heath plant communities dominated by Calluna and by Nardus. We investigate which plant fractions are most important for $\mathrm{CO}_{2}$ uptake and which most strongly retain assimilate over six weeks during the growing season. Due to differences in relative growth rate and rate of decomposition, we hypothesise that there will be higher assimilation of ${ }^{13} \mathrm{CO}_{2}$, but also a faster turnover and subsequent lower retention of assimilate in the Nardus-compared to the Callunadominated communities.

\section{Materials and Methods}

2.1. Site Description. Experimental work was carried out at Glensaugh Research Farm, SE Grampian Highlands, Scotland $\left(56^{\circ} 54^{\prime} \mathrm{N}, 2^{\circ} 34^{\prime} \mathrm{W}\right)$. The site is at $365-390 \mathrm{~m}$ altitude with a mean annual temperature of $7.5^{\circ} \mathrm{C}$ and precipitation of $1131 \mathrm{~mm}$ [31]. The soil is a podzol with an organic horizon of $30-60 \mathrm{~cm}$ depth. The experimental site is lightly grazed all year round by sheep $\left(1.1\right.$ ewes ha $\left.{ }^{-1}\right)$ and by cattle during the summer $\left(0.25 \mathrm{cattle} \mathrm{ha}^{-1}\right)$. The main plant community is Calluna-Vaccinium myrtillus (hereafter, Vaccinium) heath (NVC H12) [32]. The Calluna sward is approximately eight years old and in the building phase of its growth cycle [10].
At this site, the Calluna-dominated vegetation forms a mosaic with graminoid-dominated vegetation, characterised as Nardus-Galium saxatile grassland (NVC U5) [33]. The moss, Hypnum jutlandicum, was abundant in both vegetation communities.

2.2. Experimental Design. In May 2009, five blocks were established within an area of approximately $80 \times 80 \mathrm{~m}$, with blocks being $>10 \mathrm{~m}$ apart. Paired plots $(40 \mathrm{~cm}$ diameter, $>5 \mathrm{~m}$ apart) of representative Calluna-dominated and Nardusdominated vegetation communities were established within each block. At each plot, a stainless steel collar was driven into the soil (to $\sim 3 \mathrm{~cm}$ ) to create a small trench, allowing for placement of a collar during labelling.

2.3. In Situ ${ }^{13} \mathrm{CO}_{2}$ Pulse Labelling. At three of the blocks stainless steel collars ( $40 \mathrm{~cm}$ diameter, $12 \mathrm{~cm}$ height) were slotted into the trenches around each plot. A transparent bell-shaped chamber (BELL060101, Haxnicks; $36 \mathrm{~cm}$ height, $40 \mathrm{~cm}$ diameter, and 281 volume) was placed onto a rubber seal (to ensure a closed headspace) on top of each collar. Each chamber was equipped with a pair of $12 \mathrm{~V} \mathrm{DC}$ fans (Sunon, $1.1 \mathrm{~W}$ ) to ensure adequate mixing of headspace gas and two suba-seals at opposite sides of the chamber for injection of ${ }^{13} \mathrm{CO}_{2}$.

Labelling took place during $10.00-17.00 \mathrm{~h}$ on the $3 \mathrm{rd}$ of June 2009. a Few drops of $1 \mathrm{M} \mathrm{HCl}$ were injected into $1.25 \mathrm{~g}$ of $99 \%{ }^{13} \mathrm{C}$-enriched sodium bicarbonate $\left(\mathrm{NaH}^{13} \mathrm{CO}_{3}\right)$ in a gas tight jar. $5 \mathrm{~cm}^{3}$ of the ${ }^{13} \mathrm{CO}_{2}$ evolved was injected into each side of the chamber, creating a $\mathrm{CO}_{2}$ concentration of 1-2 times ambient. This was repeated approximately every $30 \mathrm{~min}$ for a total of 12 additions. To avoid overheating, chambers were removed just prior to each addition to enable mixing with ambient air. During labelling, temperature within the chambers remained between 22 and $30^{\circ} \mathrm{C}$ for $80 \%$ of the time, and photosynthetic active radiation ranged from 470 to $1900 \mu \mathrm{mol} \mathrm{m}^{-2} \mathrm{~s}^{-1}$.

2.4. $\mathrm{CO}_{2}$ Flux Measurements. $\mathrm{CO}_{2}$ flux was measured on the two nonlabelled adjacent blocks during labelling and on all three labelled blocks 6 days after labelling. Measurements were made with a dynamic open system (air flow $501 \mathrm{~min}^{-1}$ ) comprising custom built transparent chambers $(281,40 \mathrm{~cm}$ diameter) attached to EGM-4 infrared gas analyser (PP Systems, Hansatech, UK). Net ecosystem exchange (NEE) and total ecosystem respiration $\left(R_{\mathrm{TOT}}\right)$ (using a blackout hood) were measured over 30 minutes each, recording 2 minute averages, and gross primary production (GPP) was calculated as the difference between NEE and $R_{\mathrm{TOT}}$ (e.g., [20]). In data presentation, $\mathrm{CO}_{2}$ assimilated is shown as negative, and $\mathrm{CO}_{2}$ emitted is shown as positive.

2.5. Sampling and Harvesting. Shoot and root biomass were sampled from each plot immediately after labelling on day 0 (initial allocation) and on days 15 and 42. Above- and belowground plant materials were collected away from the labelled plots for the determination of ${ }^{13} \mathrm{C}$ natural abundance. On 
days 0 and 15, four young stems of ericaceous shrubs (Calluna and Vaccinium) were sampled from each Calluna-dominated plot and split into leaf and stem (3-4 year old) tissues. Older Calluna stems ( $>4$ years, comprising $30 \%$ of total stem biomass) were not sampled to avoid damaging the remaining plant. Small samples of moss (Hypnum jutlandicum) and graminoid leaves (mainly Nardus) were also taken from these plots. From the Nardus-dominated plots, graminoid leaves, moss, and herbs (Galium saxatile and Potentilla erecta) were sampled. Two soil cores $(2.1 \mathrm{~cm}$ diameter, $10.5 \mathrm{~cm}$ depth) were taken from each plot for root samples. After 42 days, all above-ground vegetation and further four soil cores were taken from each plot.

2.6. Growth Assumptions. To determine the amount of ${ }^{13} \mathrm{C}$ initially taken up in each plot and subsequently retained, back calculations were made from final biomass (day 42) to estimate biomass of each component of the vegetation at day 0 (= final mass $-42 *$ daily production estimate) and day 15 (= final mass $-27 *$ daily production estimate). Production estimates for ericaceous shrubs, herbs, and roots were obtained from the literature (Table 1). Due to the warm, dry weather, moss growth was assumed to be negligible over the 6week experiment [34]. Production estimates for graminoids were obtained from field measurements. Graminoid shoots $(n=60)$ in both Calluna- and Nardus-dominated areas were tagged and their length was measured on days 0,15 , and 42. Mean initial: final length ratio provided an estimate of growth rate.

2.7. ${ }^{13} \mathrm{C}$ Analysis. Samples were divided into the following plant fractions: Calluna leaf, Calluna stem (up to c. 4 years), Vaccinium leaf, Vaccinium stem, moss, graminoid leaf, herbs, and roots. Leaf samples were taken from current year's growth. Roots were extracted from soil cores by washing and sieving ( $2 \mathrm{~mm}$ sieve). Samples were dried at $80^{\circ} \mathrm{C}$ for 48 hours, weighed, and finely ground in a ball mill. Subsamples (2$5 \mathrm{mg}$ ) were analysed for ${ }^{13} \mathrm{C}$ on an elemental analyser linked to a mass spectrometer. Samples from day 0, day 15, and natural abundance were analysed on an ANCA GSL prep unit connected to a Europa Scientific 20-20 stable isotope analyser (Sercon, Crewe, UK); day 42 samples were analysed on a Flash EA 1112 Series Elemental Analyser connected via a Conflo III to a Delta ${ }^{\text {Plus }} \mathrm{XP}$ isotope ratio mass spectrometer (Thermo Finnigan, Bremen, Germany). Appropriate cross-calibration was undertaken to ensure comparability of data.

2.8. Stable Isotope Calculations and Data Analysis. The ${ }^{13} \mathrm{C}$ signatures of the natural abundance samples were within the expected range for a C3 plant assemblage [35]. To calculate the ${ }^{13} \mathrm{C}$ atom $\%$ excess of the labelled samples, the natural abundance values were subtracted from the enriched values. The amount of ${ }^{13} \mathrm{C}$ was calculated as biomass multiplied by percent $\mathrm{C}$, multiplied by the atom $\%$ excess.

2.9. Statistical Analysis. Biomass data were analysed using ANOVA. $\mathrm{CO}_{2}$ flux data were analysed using linear mixed
TABLE 1: Production estimates used for back calculating initial biomass from final biomass. Data are derived from annual production estimates from the literature with the exception of Calluna. For Calluna, the June and July production proportions [26] were applied to an annual estimate of production [27]. All data have been converted to $\mathrm{g} \mathrm{m}^{-2}$ day $^{-1}$.

\begin{tabular}{lcc}
\hline Plant tissue & $\begin{array}{c}\text { Production } \\
\mathrm{g} \mathrm{m}^{-2} \text { day }^{-1}\end{array}$ & Reference \\
\hline Calluna leaf & 1.6720 & {$[26,27]$} \\
Calluna stem & 0.1270 & {$[28]$} \\
Vaccinium leaf and stem & 0.0007 & {$[29]$} \\
Root (graminoid) & 0.7400 & {$[30]$} \\
Root (Calluna) & 0.5010 & {$[28]$} \\
Herb & 0.0140 & {$[30]$} \\
Graminoid leaf & Applied initial: final & Measured \\
Moss & biomass ratio & \\
\hline
\end{tabular}

models with flux (NEE, $R_{\mathrm{TOT}}$, and GPP) as fixed and plot nested within block, as random variables. Flux data from the two sampling days were combined as there was no significant difference between days. The analysis of ${ }^{13} \mathrm{C}$ data (both enrichment and content) was performed separately for photosynthetic tissues (Calluna leaf, Vaccinium leaf and stem, graminoid leaf, moss and herb) and nonphotosynthetic tissues (Calluna stem and roots). Linear mixed models, with repeated measures, were used to analyse the effect of time since ${ }^{13} \mathrm{CO}_{2}$ pulse and plant fraction on ${ }^{13} \mathrm{C}$ enrichment. Vegetation community was added in the analysis of ${ }^{13} \mathrm{C}$ enrichment of plant fractions common to both communities and in comparison of ${ }^{13} \mathrm{C}$ pools between communities. Time was used as a fixed repeated (autoregression 1) factor, with plot the subject of the repeated factor. Plot was also nested within block and used as a random factor. Type 1 sum of squares was used in all models. The residuals of linear mixed models were checked for normality. Post hoc testing was performed using LSD pairwise comparisons based on a significant main effect. All data were analysed using statistical package IBM SPSS statistics (version 19). Due to the in situ nature of our experiment, the number of species and thus number of $\mathrm{C}$ pools and fluxes between pools within the system, our data did not enable modelling as in Street et al. [36].

\section{Results}

3.1. $\mathrm{CO}_{2}$ Fluxes. The measurements made during and 6 days after labelling showed that there is no difference in NEE $\left(F_{1,6}=0.380, P=0.560\right), R_{\mathrm{TOT}}\left(F_{1,6}=2.067, P=0.201\right)$, or $\operatorname{GPP}\left(F_{1,6}=2.425, P=0.170\right)$ between Calluna- and Nardusdominated vegetation communities (Figure 1).

3.2. Biomass. Calluna-dominated plots tended to contain greater plant biomass than Nardus-dominated plots with $2079.7 \pm 367.3$ (SE) and $1269.9 \pm 282.1 \mathrm{~g} \mathrm{~m}^{-2}$, respectively, 


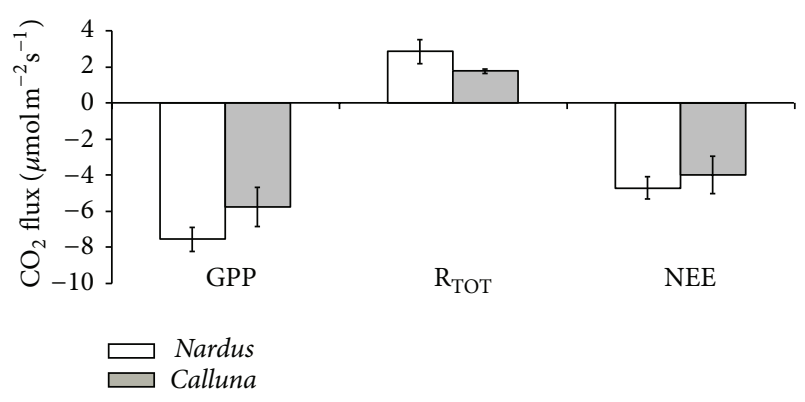

Figure 1: $\mathrm{CO}_{2}$ fluxes of Calluna-dominated and Nardus-dominated vegetation communities: GPP: gross primary production, $R_{\mathrm{TOT}}$ : total respiration, and NEE: net ecosystem exchange. Mean $(n=5) \pm$ 1 S.E.

but this was not significantly different $\left(F_{1,4}=3.1, P=\right.$ 0.155 ) (Table 2$)$. The two communities had similar amounts of photosynthetic biomass (380.2 and $310.7 \mathrm{~g} \mathrm{~m}^{-2}$ in Callunaand Nardus-dominated vegetation communities), and root material formed the largest single biomass fraction $(57 \%$ in Calluna plots, $75 \%$ in Nardus plots) (Table 2).

3.3. ${ }^{13} \mathrm{C}$ Enrichment in Plant Fractions. In the Callunadominated community, the graminoid and dwarf shrub leaves were the most ${ }^{13} \mathrm{C}$-enriched photosynthetic tissues, and their enrichment declined substantially over 42 days (Figure 2(a), Table 3). Vaccinium stem and moss were least enriched, but both increased in enrichment over 15 days before declining further after 42 days (Figure 2(a), Table 3). The effects on ${ }^{13} \mathrm{C}$ enrichment of time since ${ }^{13} \mathrm{CO}_{2}$ pulse, plant fraction, and their interaction were all significant $\left(F_{2,18}=24.7, P<0.001 ; F_{4,18}=41.5, P<0.001\right.$; and $F_{8,18}=$ $3.5, P=0.007$ resp.). These factors also influenced enrichment of nonphotosynthetic tissues (sampling day, $F_{2,9}=17.2$, $P=0.001$; plant fraction, $F_{1,9}=98.3, P<0.001$; and interaction, $\left.F_{2,9}=17.7, P=0.001\right)$. Calluna stem was initially more enriched than root material, with the latter showing increased enrichment over 15 days before decreasing to below detection by 42 days (Figure 2(b), Table 3). There was an apparent tendency towards an increase in enrichment of the Calluna stem after 15 days which was maintained at the end of the experiment (Figure 2(b), Table 3).

In the Nardus-dominated plant community, ${ }^{13} \mathrm{C}$ enrichment differed between sampling day $\left(F_{2,12}=8.2, P=0.004\right)$ and photosynthetic plant fraction $\left(F_{2,12}=25.4, P<0.001\right)$ with no interaction $\left(F_{4,12}=1.3, P=0.327\right)$. The graminoid and herb leaves were more highly enriched than the moss and remained so throughout; even though leaf enrichment declined substantially (Figure 2(c), Table 3). There was a tendency towards an increase in enrichment after 15 days in the moss tissue (Table 3). Enrichment of roots also appeared to increase after 15 days, but there was no significant influence of sampling day $\left(F_{2,6}=2.3, P=0.213\right.$ ) (Figure $2(\mathrm{~d})$ ).

Those plant fractions that occurred in both Calluna- and in Nardus-dominated plots (graminoid leaf, moss, and roots) showed similar ${ }^{13} \mathrm{C}$ enrichment in both (photosynthetic,
TABLE 2: Dry biomass of photosynthetic (white) and nonphotosynthetic (bold) plant fractions within Calluna- and Nardus-dominated communities. Mean $(n=3) \pm 1$ S.E.

\begin{tabular}{lcc}
\hline & \multicolumn{2}{c}{ Plant biomass, $\mathrm{g} \mathrm{m}^{-2}$} \\
& $\begin{array}{c}\text { Calluna-dominated } \\
\text { community }\end{array}$ & $\begin{array}{c}\text { Nardus-dominated } \\
\text { community }\end{array}$ \\
\hline Calluna leaf & $223.7 \pm 38.4$ & \\
Graminoid leaf & $18.9 \pm 13.0$ & $204.7 \pm 56.5$ \\
Vaccinium leaf & $4.1 \pm 0.8$ & \\
Vaccinium stem & $34.5 \pm 7.9$ & \\
Moss & $99.1 \pm 6.5$ & $11.6 \pm 2.8$ \\
Herb & & \\
Calluna stem & $\mathbf{5 0 7 . 7} \pm \mathbf{7 4 . 6}$ & $\mathbf{9 5 9 . 2} \pm \mathbf{2 1 7 . 2}$ \\
Root & $\mathbf{1 1 9 1 . 8} \pm \mathbf{2 6 6 . 2}$ &
\end{tabular}

TABle 3: Change in ${ }^{13} \mathrm{C}$ enrichment after 15 and 42 days (as $\%$ of initial enrichment, day 0), in photosynthetic (white) and nonphotosynthetic (bold) plant fractions within Calluna- and Nardusdominated communities. Mean $(n=3) \pm 1$ S.E.

\begin{tabular}{lcccc}
\hline \multirow{4}{*}{ Tissue } & \multicolumn{4}{c}{ Days after labelling } \\
& \% change & \pm S.E. & \% change & \pm S.E. \\
\hline Calluna-dominated & & & & \\
community & & & & \\
$\quad$ Calluna leaf & -53.7 & 3.0 & -78.7 & 1.9 \\
$\quad$ Graminoid leaf & -63.4 & 1.9 & -85.8 & 0.8 \\
Vaccinium leaf & -66.3 & 2.8 & -71.1 & 2.0 \\
Vaccinium stem & +36.3 & 39.4 & -59.3 & 26.3 \\
Moss & +60.0 & 39.0 & -100.0 & 0.0 \\
Calluna stem & $+\mathbf{5 9 . 1}$ & $\mathbf{6 2 . 5}$ & $+\mathbf{3 4 . 7}$ & $\mathbf{5 8 . 4}$ \\
Root & $\mathbf{+ 3 . 9}$ & $\mathbf{5 8 . 7}$ & $-\mathbf{1 0 0 . 0}$ & $\mathbf{0 . 0}$ \\
\hline Nardus-dominated & & & & \\
community & & & & \\
Graminoid leaf & -62.2 & 1.8 & -84.5 & 2.0 \\
Moss & +12.8 & 17.2 & -84.9 & 9.4 \\
Herb & $\mathbf{6 7 . 8}$ & 8.6 & -82.2 & 3.0 \\
Root & $+\mathbf{6 3 . 2}$ & $\mathbf{2 0 . 7}$ & $-\mathbf{5 5 . 8}$ & $\mathbf{3 7 . 4}$ \\
\hline
\end{tabular}

$F_{1,15}=3.6, P=0.072$; nonphotosynthetic, $F_{1,9}=4.8$, $P=0.094)$.

3.4. ${ }^{13} \mathrm{C}$ Content of Calluna- and Nardus-Dominated Plant Communities. The Calluna-dominated vegetation assimilated an average of $103.9 \pm 21.8 \mathrm{mg}{ }^{13} \mathrm{C} \mathrm{m}^{-2}$, with $78 \%$ and $22 \%$ initially allocated to photosynthetic (mostly in Calluna leaves) and nonphotosynthetic tissues, respectively (Figure 3). Plant fraction $\left(F_{4,18}=37.3, P<0.001\right)$, time since ${ }^{13} \mathrm{CO}_{2}$ pulse $\left(F_{2,18}=5.7, P=0.009\right)$, and their interaction $\left(F_{8,18}=4.1, P=0.002\right)$ all influenced photosynthetic tissue ${ }^{13} \mathrm{C}$ content. After six weeks, $34 \%$ of the ${ }^{13} \mathrm{C}$ initially held in photosynthetic plant parts were retained, with the majority still held in the Calluna leaves (Figure 3). Calluna 


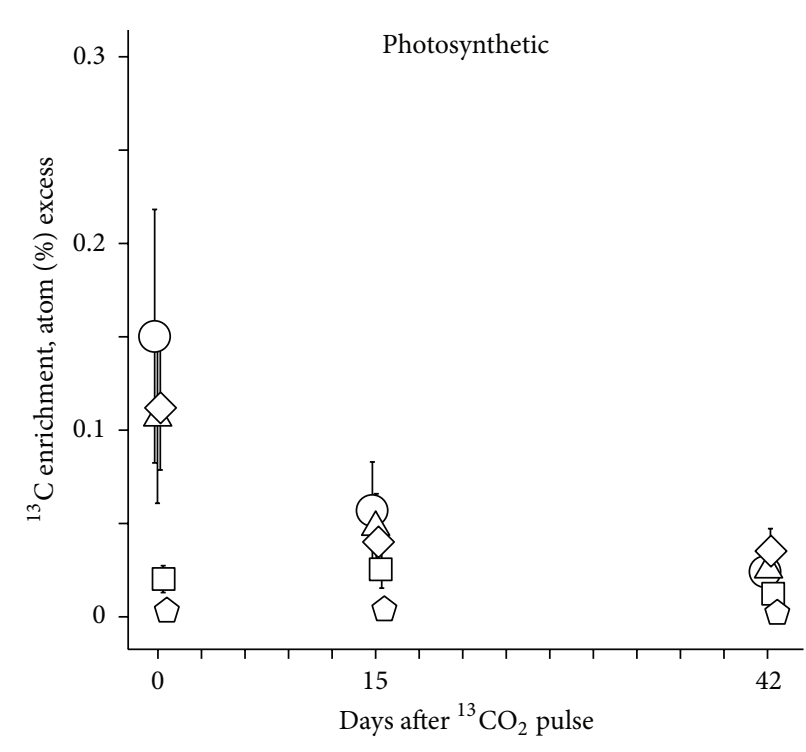

(a)

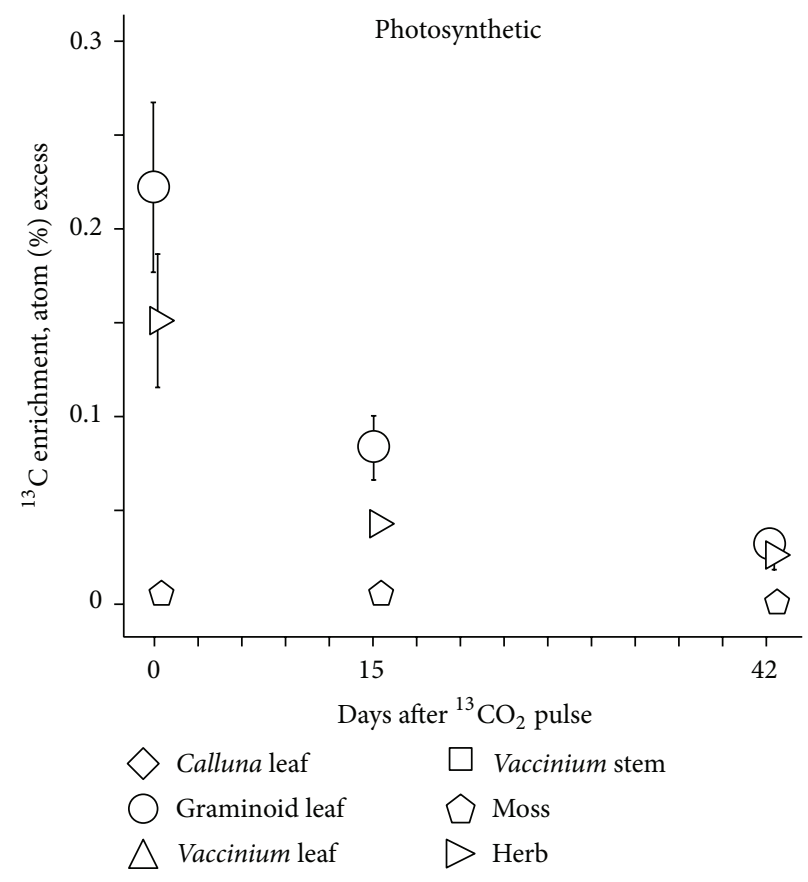

(c)

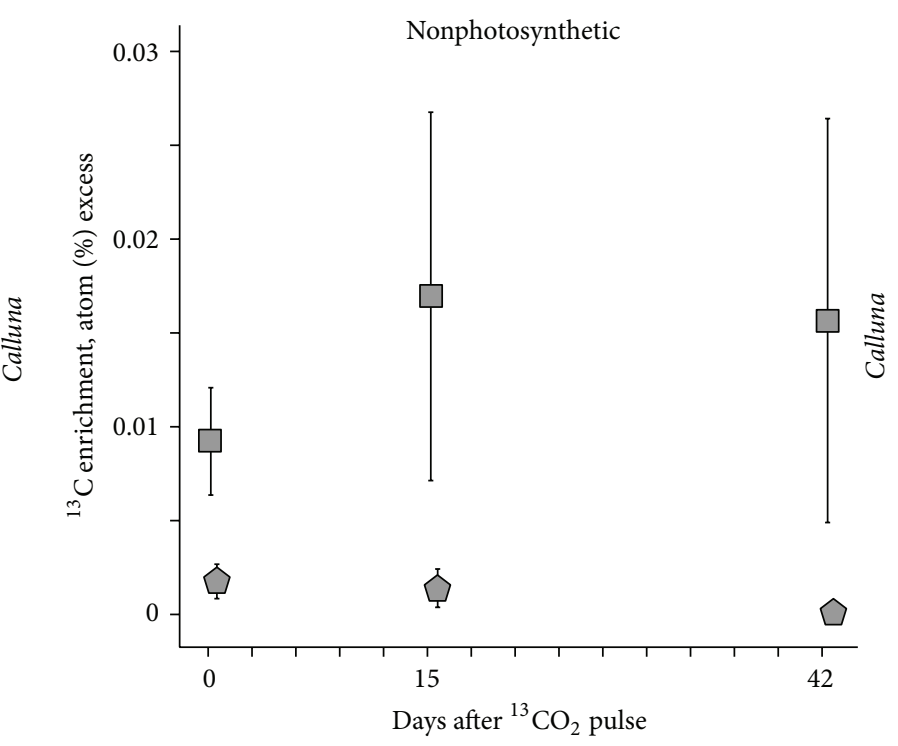

(b)

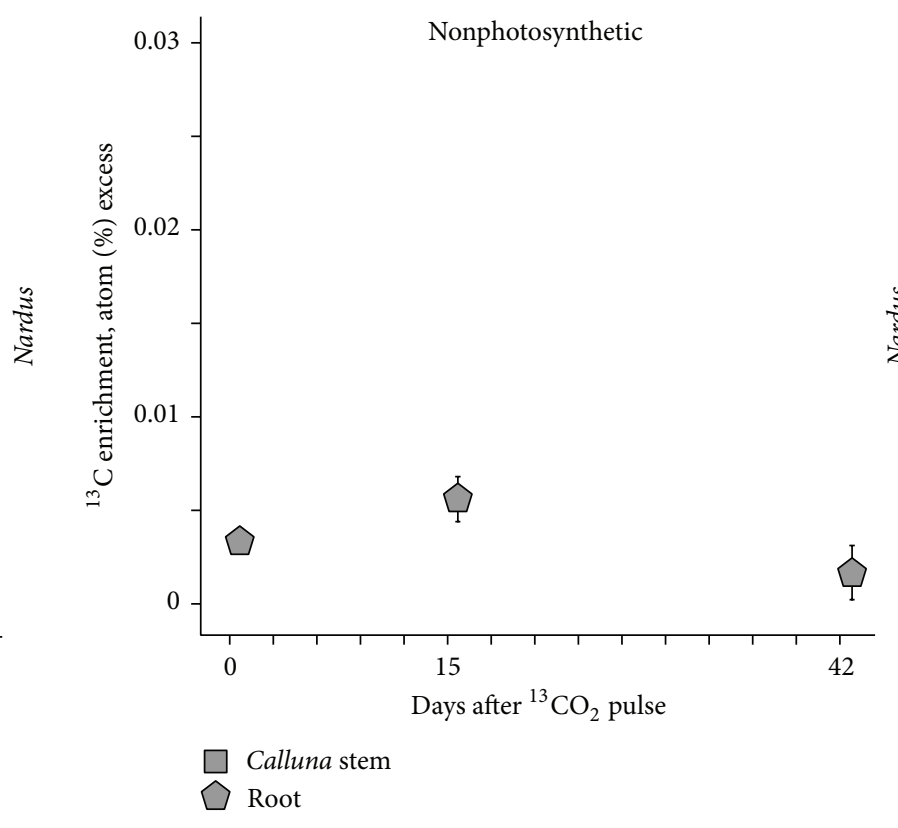

(d)

Figure 2: Time-course of ${ }^{13} \mathrm{C}$ enrichment (atom \% excess) in (a, c) photosynthetic and (b, d) nonphotosynthetic plant fractions from (a, b) Calluna-dominated and (c, d) Nardus-dominated vegetation communities. Mean $(n=3) \pm 1$ S.E.

and Vaccinium leaves retained c. $30 \%$ of their initial ${ }^{13} \mathrm{C}$ pool, whilst graminoid leaves and Vaccinium stem retained c. $50 \%$. Movement of ${ }^{13} \mathrm{C}$ assimilate within the vegetation was reflected in the slight increase in ${ }^{13} \mathrm{C}$ within the Vaccinium stem and moss and a doubling of ${ }^{13} \mathrm{C}$ in the Calluna stem over the first 15 days; this pattern was not observed in the roots. Of the ${ }^{13} \mathrm{C}$ initially allocated to nonphotosynthetic tissues, $89 \%$ remained at the end of six weeks, all of this being in Calluna stems which accumulated ${ }^{13} \mathrm{C}$, whilst roots lost all enrichment (Figure 3; plant fraction, $F_{1,9}=8.2$, $P=0.017$; time since ${ }^{13} \mathrm{CO}_{2}$ pulse, $F_{1,9}=0.3, P=$ 0.758; and interaction, $\left.F_{2,9}=0.9, P=0.455\right)$. In total, $46 \%$ of the originally assimilated ${ }^{13} \mathrm{C}$ was retained in the Calluna-dominated community after 6 weeks, with $57 \%$ and $43 \%$ of the remaining ${ }^{13} \mathrm{C}$ allocated to photosynthetic and nonphotosynthetic tissues, respectively. 


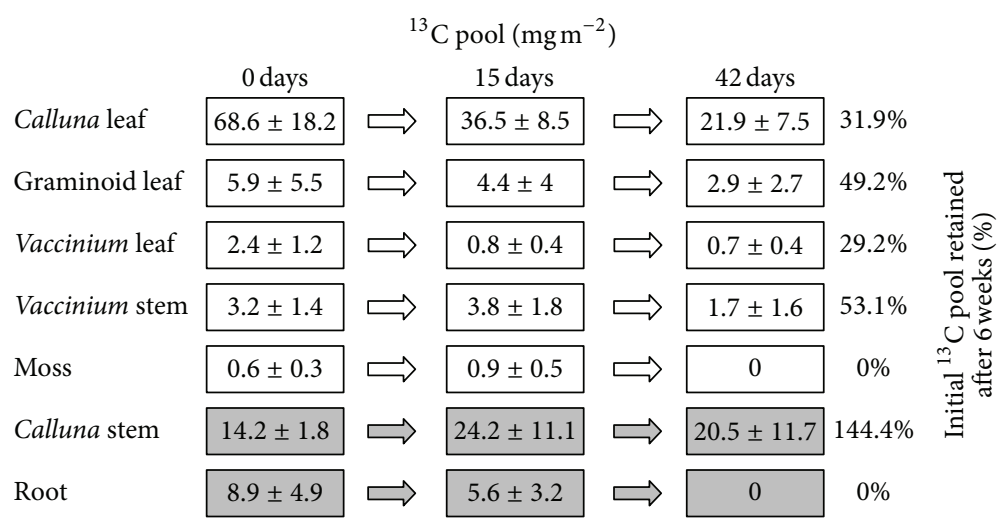

FIGURE 3: ${ }^{13} \mathrm{C}$ content $\left(\mathrm{mg} \mathrm{m}^{-2}\right.$ ) at three time points after ${ }^{13} \mathrm{CO}_{2}$ pulse labelling and ${ }^{13} \mathrm{C}$ retention (as \% of initial pool) after six weeks within photosynthetic (white) and nonphotosynthetic (shaded) plant fractions of a Calluna-dominated community. Mean $(n=3) \pm 1$ S.E.

Nardus-dominated vegetation assimilated $76.7 \pm 3.7 \mathrm{mg}$ ${ }^{13} \mathrm{C} \mathrm{m}^{-2}$, of which $82 \%$ was initially allocated to photosynthetic tissue, with most $(85 \%)$ held in graminoid leaves (Figure 4). The only nonphotosynthetic tissue, the roots, initially accounted $18 \%$ of the assimilated ${ }^{13} \mathrm{C}$. Plant fraction $\left(F_{2,12}=136.1, P<0.001\right)$, time since ${ }^{13} \mathrm{CO}_{2}$ pulse $\left(F_{2,12}=\right.$ 9.7, $P=0.001)$, and their interaction $\left(F_{4,12}=4.5, P=\right.$ 0.011 ) influenced the ${ }^{13} \mathrm{C}$ content of photosynthetic tissues in this community. ${ }^{13} \mathrm{C}$ content decreased over time, with photosynthetic tissues retaining $70 \%$ and $45 \%$ after 15 days and six weeks, respectively. Graminoid leaves remained the biggest ${ }^{13} \mathrm{C}$ pool after six weeks, retaining c. $50 \%$ of their initial content compared to $16 \%$ in moss and herbs. ${ }^{13} \mathrm{C}$ content of the nonphotosynthetic plant fraction, the roots, almost doubled after 15 days and subsequently dropped to $35 \%$ of initial pool size (time since pulse label, $F_{2,6}=8.7, P=$ 0.017 ) (Figure 4). In total, the Nardus-dominated community retained $43 \%$ of the assimilated ${ }^{13} \mathrm{C}$ over 6 weeks, with $85 \%$ and $15 \%$ of the remaining ${ }^{13} \mathrm{C}$ allocated to photosynthetic and nonphotosynthetic tissues, respectively.

3.5. Comparison of ${ }^{13} \mathrm{C}$ Dynamics in the Two Vegetation Communities. There was no difference between the two vegetation communities in the amount of ${ }^{13} \mathrm{C}$ initially assimilated or in the amount retained after six weeks (vegetation community, $F_{1,9}=0.5, P=0.506$; time since pulse label, $F_{2,9}=51.9, P<0.001$; and interaction, $F_{2,9}=1.5, P=$ 0.270 ). Graminoids were responsible for a much greater part of total $\mathrm{C}$ dynamics in the graminoid community, due to their dominance, but their leaves exhibited similar ${ }^{13} \mathrm{C}$ enrichment and retention in both communities. Moss also behaved similarly in both communities, representing a tiny fraction of $\mathrm{C}$ assimilation and retention despite its substantial biomass. The dynamics of ${ }^{13} \mathrm{C}$ in the roots differed between the two communities (vegetation community, $F_{1,9}=11.4, P=0.006$; time since ${ }^{13} \mathrm{CO}_{2}$ pulse, $F_{2,9}=7.2, P=0.009$; interaction $\left.F_{2,9}=2.1, P=0.165\right)$. Initially, the roots accounted for $22 \%$ of the assimilate in the graminoid community and half this proportion (11\%) in the Calluna vegetation. The graminoid roots continued to accumulate ${ }^{13} \mathrm{C}$ over 15 days and after six weeks still retained approximately one-third of their initial ${ }^{13} \mathrm{C}$ content, whilst the Calluna community roots lost ${ }^{13} \mathrm{C}$ over the entire period and did not retain any after six weeks. A clear difference between the communities is the presence in the Calluna community of woody stem tissue which accumulated ${ }^{13} \mathrm{C}$ during the experiment and accounted for $43 \%$ of the ${ }^{13} \mathrm{C}$ remaining after 6 weeks.

\section{Discussion}

The use of ${ }^{13} \mathrm{CO}_{2}$ pulse labelling within an upland heath demonstrated that, contrary to our hypothesis, there were no significant differences between Calluna- and Nardusdominated communities in the amount of ${ }^{13} \mathrm{CO}_{2}$ assimilated or the proportion of ${ }^{13} \mathrm{C}$ retained over six weeks. Whilst this study represents a short snapshot in time, it nevertheless provides a useful comparison of ${ }^{13} \mathrm{C}$ assimilate dynamics in these two contrasting plant communities.

4.1. C fluxes in Calluna- and Graminoid-Dominated Communities. Graminoid-dominated vegetation has been previously shown to have greater gross $\mathrm{CO}_{2}$ fluxes and ${ }^{13} \mathrm{CO}_{2}$ uptake than dwarf shrub vegetation $[20,37,38]$. In contrast to these studies, we observed no difference in measured $\mathrm{CO}_{2}$ fluxes between the graminoid- and Calluna-dominated communities during the growing season. The graminoid-dominated community was mostly composed of Nardus, which has a lower growth rate than other grasses, it associates with, for example, Agrostis canina and Holcus lanatus, but a higher relative growth rate than Calluna [21]. However, the Calluna was in the "building phase" of its life cycling and so exhibiting high productivity which could explain their similarity in $\mathrm{CO}_{2}$ cycling [10]. The age of the Calluna studied by Ward et al. [20] and Trinder et al. [38] is unknown, but this is likely to influence $\mathrm{C}$ assimilation. Furthermore, these studies were in deep peat ecosystems with different dominant graminoids (e.g., Eriophorum species) to those commonly associated with changes in upland heath management practices. In our study, both photosynthetic biomass and $\mathrm{CO}_{2}$ fluxes were similar 


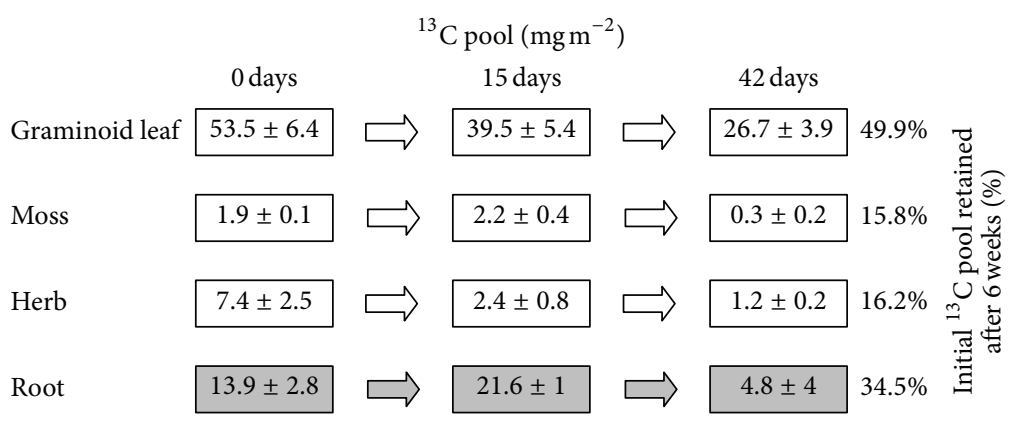

Figure $4:{ }^{13} \mathrm{C}$ content $\left(\mathrm{mg} \mathrm{m}^{-2}\right.$ ) at three time points after ${ }^{13} \mathrm{CO}_{2}$ pulse labelling and ${ }^{13} \mathrm{C}$ retention (as \% of initial pool) after six weeks within photosynthetic (white) and nonphotosynthetic (shaded) plant fractions of a Nardus-dominated community. Mean $(n=3) \pm 1$ S.E.

in the two communities, hence their similarity in ${ }^{13} \mathrm{CO}_{2}$ assimilation in early summer.

4.2. Assimilation and Translocation of ${ }^{13} \mathrm{CO}_{2}$. In the Callunadominated community, graminoid and dwarf shrub leaves had a similar ${ }^{13} \mathrm{CO}_{2}$ assimilation rate (reflected in initial enrichment), which was much greater than that of the moss and the photosynthetic stems of Vaccinium. Other studies have shown higher ${ }^{13} \mathrm{CO}_{2}$ uptake by graminoids than by ericaceous shrubs $[20,38,39]$, although these may have included some stem material in shoot samples which could have diluted the shrub ${ }^{13} \mathrm{C}$ signature. In the Nardus-dominated community, the graminoids and herbs assimilated ${ }^{13} \mathrm{C}$ most rapidly, and the mosses again had very low assimilation rate. Graminoid and moss assimilation rates were similar in the two plant communities showing that Calluna was not creating more shading effect than the graminoid canopy, as has been noted previously [20].

There was a sharp decline in ${ }^{13} \mathrm{C}$ enrichment in the photosynthetically active tissues of the vascular plants over 15 days (by $56 \%$ on average) with a more gradual decline over the following 27 days ( $79 \%$ decline over the whole 42 days). The rate of decrease in enrichment is similar to recent peatland tracer studies in which graminoid and dwarf shrub shoots lost $68 \%$ and $63 \%$ of enrichment, respectively, over 21 days [20], and Calluna shoots lost $60 \%$ of enrichment over 30 days [38]. This decline can be attributed to shoot respiration, to rapid allocation of ${ }^{13} \mathrm{C}$ below-ground to roots (as was most evident in the Nardus-dominated community) and microbial biomass [40, 41], and to translocation of assimilate to other plant parts such as Calluna stem.

Nonphotosynthetic tissues, that is, Calluna stems and, to a much lesser extent, the roots of both vegetation communities were ${ }^{13} \mathrm{C}$ enriched immediately after labelling, showing evidence of rapid translocation of assimilate. Rapid allocation of fixed $\mathrm{C}$ to the roots has also been shown in an upland grassland tracer study only after 4 hours of labelling [42] with maximum enrichment 21-48 h after labelling [41, 42]. The timing of our sampling meant that we may have missed the enrichment peak in the roots, but we did detect an increase after 15 days. Calluna stem enrichment was also increased after 15 days and maintained thereafter as ${ }^{13} \mathrm{C}$ was transported from the leaves to this carbohydrate store [43].

In both vegetation communities, the moss had minimal initial ${ }^{13} \mathrm{C}$ enrichment but showed a slight increase after 15 days before losing most of the tracer again. Similar low enrichment has been observed in moss in Callunadominated vegetation [20] and may be explained by the lower photosynthetic rates of mosses than vascular plants and their shaded position at the bottom of the canopy. Much higher enrichment and subsequent retention has been achieved when ${ }^{13} \mathrm{CO}_{2}$ has been applied to moss in the absence of vascular plants in peatland and arctic tundra communities in which mosses dominate $[36,44,45]$. A large proportion of the $\mathrm{CO}_{2}$ fixed by mosses originates from soil respiration [46], which could be the source of the ${ }^{13} \mathrm{C}$ acquired by the moss in the heathland after 15 days.

4.3. Retention of ${ }^{13} \mathrm{C}$ in the Vegetation. Both immediately after labelling and six weeks later, when over $40 \%$ of the ${ }^{13} \mathrm{C}$ was still retained by both vegetation communities, the majority of the label was contained in the photosynthetically active tissues of the dominant plant groups. Although similar amounts of ${ }^{13} \mathrm{C}$ were both assimilated and retained in both communities, the pool of ${ }^{13} \mathrm{C}$ within each plant fraction, and hence community, may differ in its residence time. For example, the Calluna stems accumulated ${ }^{13} \mathrm{C}$ over two weeks and retained it thereafter such that they contained a significant proportion of the total ${ }^{13} \mathrm{C}$ pool after 6 weeks. This ${ }^{13} \mathrm{C}$ may have been incorporated into lignin or ligninlike compounds which are recalcitrant and thus exhibit a longer residence time in the soil [47]. C will be retained longer in Calluna leaves, which survive several years [48], than in Nardus leaves which senesce (at least partially) each autumn [49]. Calluna leaves also contain higher concentrations of recalcitrant C-based secondary metabolites than heathland grasses and so will decompose more slowly [50, 51]. Thus, although the Nardus- and Calluna-dominated vegetation communities studied had similar $\mathrm{C}$ sequestration rate and 
retention of assimilate over 6 weeks, it is likely that the residence of assimilated $\mathrm{C}$ will be longer in the Calluna community.

The roots in both vegetation types contained rather a small proportion of the ${ }^{13} \mathrm{C}$ that remained six weeks after labeling, but, of the remaining ${ }^{13} \mathrm{C}$, there was a higher allocation to roots in the Nardus- than in the Calluna-dominated communities. This may reflect the one-year lifespan of Nardus roots [52] and hence a greater requirement to allocate $\mathrm{C}$ to root growth than in Calluna which has a slower root turnover $[53,54]$.

\section{Conclusion}

This study has shown similar $\mathrm{C}$ assimilation and retention over six weeks by a Calluna-dominated community, typical of traditional low intensity management, and graminoiddominated vegetation such as typically results from heavy grazing and/or overfrequent burning. Calluna- and Nardus-dominated communities assimilated $103.9 \pm 21.8$ and $76.7 \pm 3.7 \mathrm{mg}^{13} \mathrm{C} \mathrm{m}^{-2}$, respectively, after six weeks with $46 \%$ and $43 \%$ retained, respectively, over the period. However, consideration of the strategies of the dominant species and the attributes of the tissues in which ${ }^{13} \mathrm{C}$ was retained has suggested that Calluna-dominated vegetation may be of greater benefit to carbon sequestration in the longer term.

5.1. Application. The current trend in upland management is for a decrease, or even removal, of livestock grazing [55] which reduces a strong driver of the transition from Calluna- to graminoid-dominated heath and, where Calluna has persisted within the graminoid plant community, may result in recovery of shrub cover (e.g., [56]). In the light of our findings, this trend may represent positive management for $\mathrm{C}$ sequestration by upland heath.

\section{Conflict of Interests}

The authors do not have a direct financial relation with the commercial identity mentioned in the present paper.

\section{Acknowledgments}

Samuel Quin was supported by a Scottish Natural Heritage Ph.D. studentship. The authors thank the James Hutton Institute (JHI), Glensaugh Research Station for field site access and Janet Woo from the University of Aberdeen and Barry Thornton (JHI) for isotope analysis.

\section{References}

[1] R. Lal, "Agricultural activities and the global carbon cycle," Nutrient Cycling in Agroecosystems, vol. 70, no. 2, pp. 103-116, 2004.

[2] EASAC, "Ecosystem services and Biodiversity in Europe," 2009, http://www.easac.eu/fileadmin/PDF_s/reports_statements/ Ecosystems.pdf.
[3] Secretariat of the Convention on Biological Diversity, Ecosystem Goods and Services in Development Planning: A Good Practice Guide, Montreal, Canada, 2010.

[4] N. Stern, The Economics of Climate Change: the Stern Review, Cambridge University Press, Cambridge, UK, 2006.

[5] N. J. Ostle, P. E. Levy, C. D. Evans, and P. Smith, "UK land use and soil carbon sequestration," Land Use Policy, vol. 26, no. 1, pp. S274-S283, 2009.

[6] J. J. C. Dawson and P. Smith, "Carbon losses from soil and its consequences for land-use management," Science of the Total Environment, vol. 382, no. 2-3, pp. 165-190, 2007.

[7] W. M. Post and K. C. Kwon, "Soil carbon sequestration and land-use change: processes and potential," Global Change Biology, vol. 6, no. 3, pp. 317-327, 2000.

[8] P. D. Carey, S. Wallis, P. M. Chamberlain et al., "Countryside Survey: UK Results from 2007," NERC/Centre for Ecology \& Hydrology (CEH Project Number: C03259), pp. 105, 2008.

[9] B. A. Emmett, B. Reynolds, P. M. Chamberlain et al., "Countryside survey: soils report from 2007," Tech. Rep. 9/07, NERC/Centre for Ecology \& Hydrology, 2010, CEH Project Number: C03259.

[10] C. H. Gimingham, An Introduction To Heathland Ecology, Oliver \& Boyd, Edinburgh, UK, 1975.

[11] J. M. Williams, Common Standards Monitoring For Designated Sites: First Six Year Report, JNCC, Peterborough, UK, 2006.

[12] J. Holden, L. Shotbolt, A. Bonn et al., "Environmental change in moorland landscapes," Earth-Science Reviews, vol. 82, pp. 75100, 2007.

[13] M. J. Chadwick, “Nardus stricta L.”’ Journal of Ecology, vol. 48, pp. 255-267, 1960.

[14] S. A. Grant, L. Torvell, E. M. Sim, J. L. Small, and R. H. Armstrong, "Controlled grazing studies on Nardus grassland: effects of between-tussock sward height and species of grazer on Nardus utilization and floristic composition in two fields in Scotland," Journal of Applied Ecology, vol. 33, no. 5, pp. 10531064, 1996.

[15] F. S. Chapin, "Effects of plant traits on ecosystem and regional processes: a conceptual framework for predicting the consequences of global change," Annals of Botany, vol. 91, no. 4, pp. 455-463, 2003.

[16] G. B. De Deyn, J. H. C. Cornelissen, and R. D. Bardgett, "Plant functional traits and soil carbon sequestration in contrasting biomes," Ecology Letters, vol. 11, no. 5, pp. 516-531, 2008.

[17] G. B. De Deyn, H. Quirk, Z. Yi, S. Oakley, N. J. Ostle, and R. D. Bardgett, "Vegetation composition promotes carbon and nitrogen storage in model grassland communities of contrasting soil fertility," Journal of Ecology, vol. 97, no. 5, pp. 864-875, 2009.

[18] J. R. Mclaren and R. Turkington, "Plant functional group identity differentially affects leaf and root decomposition," Global Change Biology, vol. 16, no. 11, pp. 3075-3084, 2010.

[19] S. E. Ward, R. D. Bardgett, N. P. McNamara, J. K. Adamson, and N. J. Ostle, "Long-term consequences of grazing and burning on northern peatland carbon dynamics," Ecosystems, vol. 10, no. 7, pp. 1069-1083, 2007.

[20] S. E. Ward, R. D. Bardgett, N. P. McNamara, and N. J. Ostle, "Plant functional group identity influences short-term peatland ecosystem carbon flux: evidence from a plant removal experiment," Functional Ecology, vol. 23, no. 2, pp. 454-462, 2009.

[21] J. P. Grime and R. Hunt, "Relative growth-rate: its range and adaptive significance in a local flora," Journal of Ecology, vol. 63, pp. 393-422, 1975. 
[22] M. A. F. Jalal, D. J. Read, and E. Haslam, "Phenolic composition and its seasonal variation in Calluna vulgaris," Phytochemistry, vol. 21, no. 6, pp. 1397-1401, 1982.

[23] P. B. Reich, M. B. Walters, and D. S. Ellsworth, "Leaf life-span in relation to leaf, plant, and stand characteristics among diverse ecosystems," Ecological Monographs, vol. 62, no. 3, pp. 365-392, 1992.

[24] E. W. Sulzman, J. B. Brant, R. D. Bowden, and K. Lajtha, "Contribution of aboveground litter, belowground litter, and rhizosphere respiration to total soil $\mathrm{CO}_{2}$ efflux in an old growth coniferous forest," Biogeochemistry, vol. 73, no. 1, pp. 231-256, 2005.

[25] J. H. C. Cornelissen, S. I. Lang, N. A. Soudzilovskaia, and H. J. During, "Comparative cryptogam ecology: a review of bryophyte and lichen traits that drive biogeochemistry," Annals of Botany, vol. 99, no. 5, pp. 987-1001, 2007.

[26] S. C. F. Palmer, "Prediction of the shoot production of heather under grazing in the uplands of Great Britain," Grass and Forage Science, vol. 52, no. 4, pp. 408-424, 1997.

[27] S. A. Grant, "The measurement of primary production and utilisation on heather moors," Journal of the British Grassland Society, vol. 26, pp. 51-58, 1971.

[28] H. E. Jones and A. J. P. Gore, "A simulation of production and decay in blanket bog," in Production Ecology of British Moors and Montane Grasslands, O. W. Heal and D. F. Perkins, Eds., vol. 27 of Ecological Studies, pp. 160-186, Springer, Berlin, Germany, 1978.

[29] G. I. Forrest and R. A. H. Smith, "The productivity of a range of blanket bog vegetation types in the Northern Pennines," Journal of Ecology, vol. 63, pp. 173-202, 1975.

[30] D. F. Perkins, V. Jones, R. O. Millar, and P. Neep, "Primary production, mineral nutrients and litter decomposition in the grassland ecosystem," in Production Ecology of British Moors and Montane Grasslands, O. W. Heal and D. F. Perkins, Eds., vol. 27 of Ecological Studies, pp. 304-331, Springer, New York, NY, USA, 1978.

[31] Environmental Change Network, "ECN Sites: Glensaugh,” 2011, http://www.ecn.ac.uk/sites/ecnsites.asp?site=T02.

[32] J. S. Rodwell, British Plant Communities, vol. 2 of Mires and Heaths, Cambridge University Press, Cambridge, UK, 1991.

[33] J. S. Rodwell, British Plant Communities, vol. 3 of Grasslands and Montane Communities, Cambridge University Press, Cambridge, UK, 1992.

[34] M. Campioli, R. Samson, A. Michelsen, S. Jonasson, R. Baxter, and R. Lemeur, "Nonvascular contribution to ecosystem NPP in a subarctic heath during early and late growing season," Plant Ecology, vol. 202, no. 1, pp. 41-53, 2009.

[35] T. W. Boutton, "Stable carbon isotope ratios of natural materials:1. Sample preparation and mass spectrometric analysis," in Carbon Isotope Techniques, D. C. Coleman and B. Fry, Eds., pp. 155-186, Academic Press, London, UK, 1991.

[36] L. E. Street, J. A. Subke, M. Sommerkorn, A. Heinemeyer, and M. Williams, "Turnover of recently assimilated carbon in arctic bryophytes," Oecologia, vol. 167, pp. 325-337, 2011.

[37] N. P. McNamara, T. Plant, S. Oakley, S. Ward, C. Wood, and N. Ostle, "Gully hotspot contribution to landscape methane $\left(\mathrm{CH}_{4}\right)$ and carbon dioxide $\left(\mathrm{CO}_{2}\right)$ fluxes in a northern peatland," Science of the Total Environment, vol. 404, no. 2-3, pp. 354-360, 2008.

[38] C. J. Trinder, R. R. E. Artz, and D. Johnson, "Contribution of plant photosynthate to soil respiration and dissolved organic carbon in a naturally recolonising cutover peatland," Soil Biology and Biochemistry, vol. 40, no. 7, pp. 1622-1628, 2008.

[39] P. M. Currey, D. Johnson, L. A. Dawson et al., "Five years of simulated atmospheric nitrogen deposition have only subtle effects on the fate of newly synthesized carbon in Calluna vulgaris and Eriophorum vaginatum," Soil Biology and Biochemistry, vol. 43, no. 3, pp. 495-502, 2011.

[40] J. L. Butler, P. J. Bottomley, S. M. Griffith, and D. D. Myrold, "Distribution and turnover of recently fixed photosynthate in ryegrass rhizospheres," Soil Biology and Biochemistry, vol. 36, no. 2, pp. 371-382, 2004.

[41] J. R. Leake, N. J. Ostle, J. I. Rangel-Castro, and D. Johnson, "Carbon fluxes from plants through soil organisms determined by field ${ }^{13} \mathrm{CO}_{2}$ pulse-labelling in an upland grassland," Applied Soil Ecology, vol. 33, no. 2, pp. 152-175, 2006.

[42] D. Johnson, J. R. Leake, N. Ostle, P. Ineson, and D. J. Read, "In situ ${ }^{13} \mathrm{CO}_{2}$ pulse-labelling of upland grassland demonstrates a rapid pathway of carbon flux from arbuscular mycorrhizal mycelia to the soil," New Phytologist, vol. 153, no. 2, pp. 327-334, 2002.

[43] J. J. M. Berdowski and H. Siepel, "Vegetative regeneration of Calluna vulgaris at different ages and fertilizer levels," Biological Conservation, vol. 46, no. 2, pp. 85-93, 1988.

[44] N. Fenner, N. Ostle, C. Freeman, D. Sleep, and B. Reynolds, "Peatland carbon afflux partitioning reveals that Sphagnum photosynthate contributes to the DOC pool," Plant and Soil, vol. 259, no. 1-2, pp. 345-354, 2004.

[45] S. J. Woodin, R. Van der Wal, M. Sommerkorn, and J. L. Gornall, "Differential allocation of carbon in mosses and grasses governs ecosystem sequestration: a ${ }^{13} \mathrm{C}$ tracer study in the high Arctic," New Phytologist, vol. 184, no. 4, pp. 944-949, 2009.

[46] M. Sommerkorn, M. Bölter, and L. Kappen, "Carbon dioxide fluxes of soils and mosses in wet tundra of Taimyr Peninsula, Siberia: controlling factors and contribution to net system fluxes," Polar Research, vol. 18, no. 2, pp. 253-260, 1999.

[47] A. Heim and M. W. I. Schmidt, "Lignin turnover in arable soil and grassland analysed with two different labelling approaches," European Journal of Soil Science, vol. 58, no. 3, pp. 599-608, 2007.

[48] C. H. Gimingham, "flora of the British Isles: Calluna Salisb. A monotypic genus," Journal of Ecology, vol. 48, pp. 455-483, 1960.

[49] S. A. Grant, L. Torvell, E. M. Sim, J. L. Small, and D. A. Elston, "Seasonal pattern of leaf growth and senescence of Nardus stricta and responses of tussocks to differing severity, timing and frequency of defoliation," Journal of Applied Ecology, vol. 33, no. 5, pp. 1145-1155, 1996.

[50] T. K. Bhat, B. Singh, and O. P. Sharma, "Microbial degradation of tannins-a current perspective," Biodegradation, vol. 9, no. 5, pp. 343-357, 1998.

[51] J. D. Hofland-Zijlstra and F. Berendse, "The effect of nutrient supply and light intensity on tannins and mycorrhizal colonisation in Dutch heathland ecosystems," Plant Ecology, vol. 201, no. 2, pp. 661-675, 2009.

[52] T. A. J. Van der Krift and F. Berendse, "Root life spans of four grass species from habitats differing in nutrient availability," Functional Ecology, vol. 16, no. 2, pp. 198-203, 2002.

[53] R. Aerts, C. Bakker, and H. De Caluwe, "Root turnover as determinant of the cycling of $\mathrm{C}, \mathrm{N}$, and $\mathrm{P}$ in a dry heathland ecosystem," Biogeochemistry, vol. 15, no. 3, pp. 175-190, 1992.

[54] M. S. Carbone and S. E. Trumbore, "Contribution of new photosynthetic assimilates to respiration by perennial grasses and shrubs: residence times and allocation patterns," New Phytologist, vol. 176, no. 1, pp. 124-135, 2007. 
[55] C. Morgan-Davies and A. Waterhouse, "Hill and upland areas: livestock farming changes and stakeholders preferences," Annals of Applied Biology, vol. 85, pp. 49-55, 2008.

[56] P. D. Hulme, B. G. Merrell, L. Torvell, J. M. Fisher, J. L. Small, and R. J. Pakeman, "Rehabilitation of degraded Calluna vulgaris (L.) Hull-dominated wet heath by controlled sheep grazing," Biological Conservation, vol. 107, no. 3, pp. 351-363, 2002. 

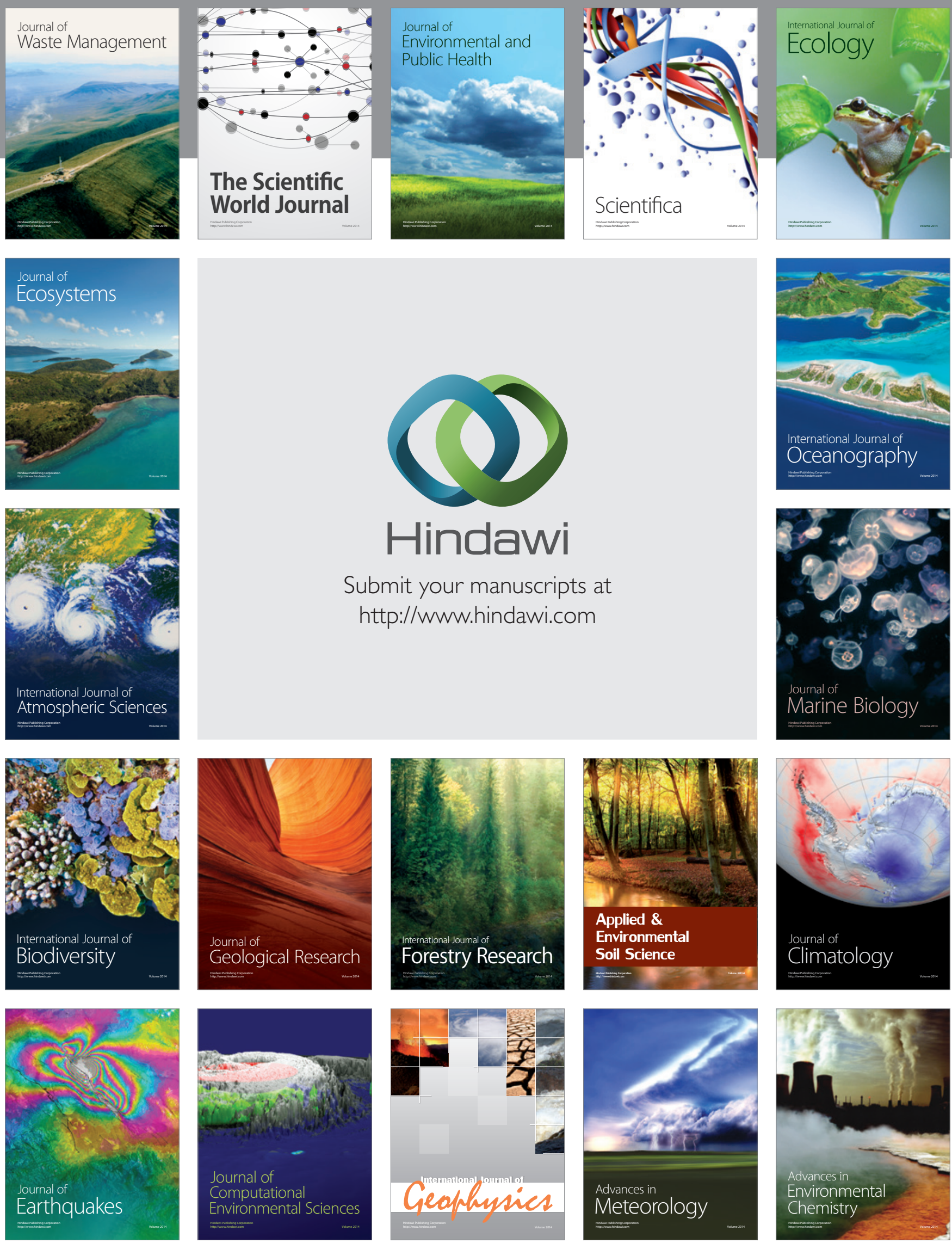